\title{
THE HOAX OF OCEAN ACIDIFICATION
}

\author{
CLIFFord OlLIER @ \\ The University of Western Australia, Perth, Australia \\ Manuscript received: July 11, 2019 \\ Revised version: July 30, 2019
}

\begin{abstract}
Ollier C., 2019. The hoax of ocean acidification. Quaestiones Geographicae 38(3), Bogucki Wydawnictwo Naukowe, Poznań, pp. 59-66. 1 fig.

AвstRAct: A widespread alarm is sweeping the world at present about the ill effects of man-made increases in carbon dioxide $\left(\mathrm{CO}_{2}\right)$ production. One aspect is that it may cause the ocean to become acid, and dissolve the carbonate skeletons of many living things including shellfish and corals. However, the oceans are not acid, never have been in geological history, and cannot become acid in the future. Changes in atmospheric $\mathrm{CO}_{2}$ cannot produce an acid ocean. Marine life depends on $\mathrm{CO}_{2}$, and some plants and animals fix it as limestone. Over geological time enormous amounts of $\mathrm{CO}_{2}$ have been sequestered by living things, and today there is far more $\mathrm{CO}_{2}$ in limestones than in the atmosphere or ocean. Carbon dioxide in seawater does not dissolve coral reefs, but is essential to their survival.
\end{abstract}

KEY WORDS: ocean, acidification, coral, limestone, $\mathrm{pH}$

Corresponding author: Clifford Ollier, cliff.ollier@uwa.edu.au

\section{Introduction}

I shall first put ocean acidification in context. In the debates about Global Warming, the alarmists maintain that warming is caused almost exclusively by anthropogenic carbon dioxide. The models of the Intergovernmental Panel on Climate Change, for instance, use only carbon dioxide, enhanced by water vapour (IPCC 2018). They do not consider other factors, even the sun, have any significant contribution at all. Yet in daily life, it is clear that warming of the Earth is caused by the sun. Every day we all observe that it is warm when the sun is shining and goes cold at night. The term Global Warming has been replaced largely by the less specific Climate Change, but it must be stressed that carbon dioxide can only produce warming: the deceptive change of name does not change the alleged process.
The concept of ocean acidification is a recent phenomenon ${ }^{1}$. The phrase was invented out of thin air in 2003 by Ken Caldeira, and is not found in older literature. It has since exploded into thousands of newspaper reports, journal articles, and alarmist publications from environmental organizations. Caldeira and Wickett (2003) wrote: Most carbon dioxide released into the atmosphere as a result of the burning of fossil fuels will eventually be absorbed by the ocean, with potentially adverse consequences for marine biota. Here we quantify the changes in ocean $\mathrm{pH}$ that may result from this continued release of $\mathrm{CO}_{2}$ and compare these with $\mathrm{pH}$ changes estimated from geological and historical records. We find that oceanic absorption of $\mathrm{CO}_{2}$ from fossil fuels may result in larger $\mathrm{pH}$ changes over the next several centuries than any inferred from the geological record of the past 300 mil-

1 For the Ocean Acidification Database see www.co2science.org/data/acidification/acidification.php 
lion years, with the possible exception of those resulting from rare, extreme events such as bolide impacts or catastrophic methane hydrate degassing.

This set the scene for future acid alarmism.

Proponents of this hypothesis demonize carbon dioxide further by claiming that increasing carbon dioxide causes the ocean to become more acid, which dissolves carbonate. To provide just one example from NASA, see Global Climate Change - Vital Signs of the Planet (NASA 2019), which includes: Ocean acidification. Since the beginning of the Industrial Revolution, the acidity of surface ocean waters has increased by about 30 percent. This increase is the result of humans emitting more carbon dioxide into the atmosphere and hence more being absorbed into the oceans. The amount of carbon dioxide absorbed by the upper layer of the oceans is increasing by about 2 billion tons per year.

This despite the fact that the oceans are alkaline, with a $\mathrm{pH}$ about 8.2 , and have been alkaline throughout their existence on Earth. We are implored to reduce the production of anthropogenic carbon dioxide to protect the ocean. We cannot ignore the magnitude of the alarm, and the journalist James Delingpole (2014) wrote that the ocean acidification could turn out to be the biggest con since Michael Mann's Hockey Stick.

In this article, I show that such claims are baseless, and indeed that carbon dioxide is beneficial to the ocean.

\section{Chemistry, $\mathrm{pH}$ and the meaning of acid}

Acid is an emotive word to the general public, which is why it is seized upon by the alarmists in their search for yet another scare. In reality increasing $\mathrm{CO}_{2}$ makes the ocean become less alkaline, but never acid. The alarmists explain their problem this way. Ocean acidification occurs when $\mathrm{CO} 2$ is absorbed into seawater. It reacts with water molecules $\left(\mathrm{H}_{2} \mathrm{O}\right)$ to form carbonic acid $\left(\mathrm{H}_{2} \mathrm{CO}_{3}\right)$ :

$$
\mathrm{CO}_{2}+\mathrm{H}_{2} \mathrm{O}>\mathrm{HCO}_{3} \text {. }
$$

The carbonic acid then allegedly dissolves calcium carbonate (shells, corals, etc.). In reality the important reaction is:

$$
\mathrm{CO}_{2}+\mathrm{CaO}>\mathrm{CaCO}_{3}
$$

In words, carbon dioxide reacts with calcium oxide to make calcium carbonate, which forms the shells and skeletons of aquatic organisms.

$\mathrm{pH}$ is a measurement of the amount of hydrogen ion concentration in a solution, the log of the hydrogen ion concentration with the sign changed. Because it is a log scale, it is very hard to move a $\mathrm{pH}$ of 8.2 to 7.0 , which is neutral. The $\mathrm{pH}$ needs to be less than 7 to be acid Claims of increasing acidity in the oceans are misleading wordplay, because the ocean would not even start to be acid until the $\mathrm{pH}$ was below 7 , and increasing acidity would be further reductions in the value of $\mathrm{pH}$. This has not happened through at least the past 600 million years because it would dissolve limestones, and limestone have been deposited in the sea and not re-dissolved in the sea through all that time.

One of the factors affecting ocean $\mathrm{pH}$ is photosynthesis by plants. Experimental results show that plants grow better if $\mathrm{CO}_{2}$ is increased, and greenhouse managers commonly increase the $\mathrm{CO}_{2}$ artificially to increase crops, often by $30 \%$ or more. There is every reason to suppose that marine plants also thrive if $\mathrm{CO}_{2}$ is increased. There is also experimental evidence that carbonate secreting animals thrive in higher $\mathrm{CO}_{2}$. Herfort et al. (2008) concluded that the likely result of human emissions of $\mathrm{CO}_{2}$ would be an increase in oceanic $\mathrm{CO}_{2}$ that could stimulate photosynthesis and calcification in a wide variety of corals.

The $\mathrm{pH}$ scale is shown in Figure 1, which shows the generally accepted average seawater $\mathrm{pH}$ of 8.2 and the $\mathrm{pH}$ of a few other substances for comparison. The $\mathrm{pH}$ of seawater can be very variable. Ocean $\mathrm{pH}$ varies regionally by 0.3 , and also seasonally in a particular location by 0.3 . Rhodes Fairbridge told me that he found the daynight variation in a coral pool was 9.4 to 7.5 (personal comm.).

Marine life, including that part that fixes $\mathrm{CO}_{2}$ as the carbonate in limestones such as coral reefs, evolved on an Earth with $\mathrm{CO}_{2}$ levels many times higher than those of today, as reported by Berner and Kothavala (2001). It may be true to say that today's marine life is getting by in a $\mathrm{CO}_{2}$-deprived environment.

As just one example of the alarmist approach the Great Barrier Reef Marine Park Authority predicts that oceanic $\mathrm{pH}$ may decrease by as much as 0.4 of a $\mathrm{pH}$ unit by 2100 and that 


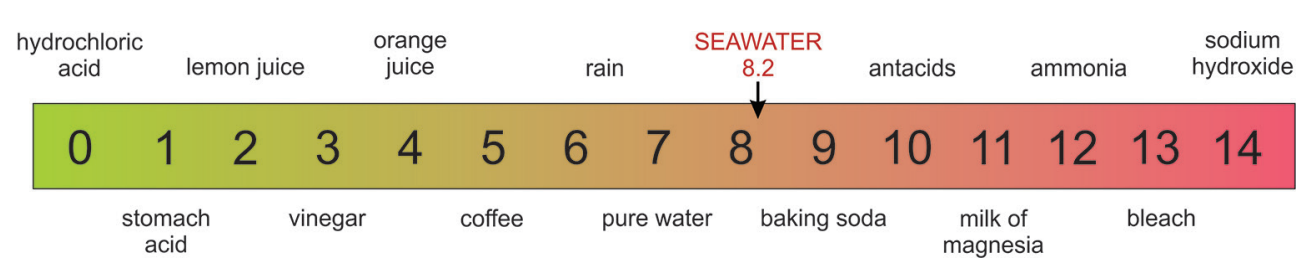

Fig. 1. Position of oceanic waters on the $\mathrm{pH}$ scale.

this will be disastrous for coral calcification. However, that oceanic $\mathrm{pH}$ would then be about 7.8 , which is still alkaline and corals can flourish at this $\mathrm{pH}$. A sample from next to a Porites coral at the Bubble Bath (described later) measured 7.74 .

The current use by alarmists of more acidic for a decreasing $p \mathrm{H}$ of alkaline water is like saying that a block of ice that has increased in temperature from $-10^{\circ} \mathrm{C}$ to $-5^{\circ} \mathrm{C}$ has become more liquid while it is still obviously solid!

\section{Carbonate Equilibrium}

Chemical equilibrium is a bit too complex to describe here, but some of the Alarmists make use of it to create scares. Gasutto and Hansson (2011) edited a book called Ocean Acidification, which has many papers with the usual alarms. Strangely there is a very level-headed Foreword by Broecker (2011), who wrote: So, one might ask, what's the problem? Unless we raise the CO2 level in the atmosphere to a level which would create huge problems for us and our fellow inhabitants of the continents, most of the surface ocean will remain supersaturated with respect to both aragonite and calcite.

Calcite is fixed by oysters, foramanifera and coccolithophores amongst others, and aragonite by corals, mussels and clams and others, so what is the problem? One problem, perhaps, is that despite the waters being supersaturated, bubbling carbon dioxide causes further increase biological activity, described later. Maybe carbon dioxide is not involved and the emissions contain other nutrients.

\section{Henry's Law}

There is another factor called Henry's Law, which states that the amount of dissolved gas in a liquid is proportional to its partial pressure above the liquid (Henry 1803). One effect is that cold water can hold more $\mathrm{CO}_{2}$ than warm, so if you warm saturated water it gives off $\mathrm{CO}_{2}$. You can see the effect if you warm a glass of fizzy drink: it goes flat. The ocean-air interface is usually rough so interchange is rapid. Actually if the aim of the Anthropogenic Global Warming activists is to keep the world cooler by reducing atmospheric $\mathrm{CO}_{2}$ they are going in the direction of decreasing alkalinity, or in their terms increasing acidification of the oceans.

It is important to note the dissolution of $\mathrm{CO}_{2}$ in water is governed by Henry's Law, evidenced by the fact there is approximately 50 times more $\mathrm{CO}_{2}$ dissolved in the ocean than in the atmosphere at present. It is this vast mass of dissolved $\mathrm{CO}_{2}$ in the ocean that holds the regulating power - not the relatively small amount of $\mathrm{CO}_{2}$ contained in the air.

Furthermore, the chemical reaction speeds involved in the dissolution of $\mathrm{CO}_{2}$ are high, as is the ocean circulation speed in the upper parts of the ocean. The ocean acidification hypothesis also ignores the presence of vast amounts of dissolved calcium in the ocean: the upper $200 \mathrm{~m}$ of ocean water contains enough dissolved calcium to bind all anthropogenic $\mathrm{CO}_{2}$ as precipitated calcium carbonate (in the ocean) without affecting the ocean's pH (Segalstad 2014).

\section{Empirical Data}

The story of $\mathrm{pH}$ measurement is not as clear as one might hope. Scientists have had $\mathrm{pH}$ meters and measurements of the oceans for over one hundred years. Doogue and Nova (2015) present the data, and note that overall the trend is messy but more up than down, and Clearly the ten year moving average of ocean $\mathrm{pH}$ since 1910 has a slight upward curve. This means that in fact the alkalinity of the ocean has increased, not decreased. It has become LESS ACIDIC. But they also tell the story of deceptive manipulation of the data, also described by Delingpole (2014). 
At the centre of the scandal is the National Oceanic and Atmospheric Administration (NOAA), the United States federal scientific agency which measures and researches changes in the oceans and atmosphere. One of NOAA's departments - the Pacific Marine Environmental Laboratory (PMEL) - also happens to be one of the mainstays of the alarmist story of ocean acidification.

Feely and Sabine (2004), two of PMEL's senior oceanographers, wrote a paper often cited in support of ocean acidification theory. It also formed part of testimony that Feely gave to Congress in 2010, to the effect that increasing atmospheric $\mathrm{CO}_{2}$ is causing a reduction in seawater $\mathrm{pH}$. It warns: The impacts of ocean acidification on shelled organisms and other animals could negatively affect marine food webs, and, when combined with other climatic changes, could substantially alter the number, variety, and health of ocean wildlife. As humans continue to send more and more carbon dioxide into the oceans, the impacts on marine ecosystems will be direct and profound and The message is clear: excessive carbon dioxide poses a threat to the health of our oceans.

But further investigation by Wallace (2015) shed doubt on these conclusions. While studying a chart produced by Feely and Sabine, Wallace noticed that some key information had been omitted. The chart only began in 1988, but Wallace knew that there were oceanic $\mathrm{pH}$ measurements dating back to at least 100 years earlier. He wondered why this solid data had been ignored, in favour of computer-modelled projections. Wallace (2015) asked Feely and Sabine why. Sabine replied that it was inappropriate for Wallace to impugn the motives or quality of our science and warned that if he continued in this manner you will not last long in your career. Having provided Wallace with a few useless leads he concluded his email by saying I hope you will refrain from contacting me again. Wallace eventually got hold of the instrumental records which Feely and Sabine had chosen to exclude and plotted a time series chart of his own, covering the period from 1910 to the present. His results were surprising. There has been $\mathrm{NO}$ reduction in oceanic $\mathrm{pH}$ levels in the last century! Could it be that global acidification is a figment of Feely's and Sabine's imagination? Wallace (2015) adds: oceanic acidification may seem like a minor issue to some but, besides being wrong, it is a crucial leg to the entire narrative of human-influenced climate change and: in whose professional world is it acceptable to omit the majority of the data and also not disclose the omission to any other soul or Congressional body?

\section{Life and Carbonates}

Many marine organisms need $\mathrm{CO}_{2}$ to make their coral skeletons, carbonate shells and so on. Corals also have symbiotic plants within their flesh that use $\mathrm{CO}_{2}$ in photosynthesis. Marine life flourishes where $\mathrm{CO}_{2}$ is abundant. Starck (2010) described the relationship between organisms and $\mathrm{pH}$ at two carbon dioxide vents, the Bubble Bath and Esa'Ala, near Dobu Island, Papua New Guinea. Here $\mathrm{CO}_{2}$ of volcanic origin is bubbling visibly through the water so that the water is saturated with $\mathrm{CO}_{2}$. Life flourishes in abundance to make the vents spectacular favourite sites for scuba divers. Starck (2010) reported many accurate measurements of $\mathrm{pH}$ in the area and concluded It seems that coral reefs are thriving at $\mathrm{pH}$ levels well below the most alarming projections. At Esa' Ala a sample taken immediately adjacent to a Porites coral and about $10 \mathrm{~cm}$ from a small bubble stream had a $\mathrm{pH}$ value of 7.96. A sample from next to a Porites coral at the Bubble Bath measured 7.74. This was about $10 \mathrm{~cm}$ from a large bubble stream and about $12 \mathrm{~m}$ from the main gas vent. A sample next to the main vent measured 6.54.

A study of seawater $\mathrm{pH}$ near active volcanic $\mathrm{CO}_{2}$ vents in the Mediterranean (Kerrison et al. 2011) found that the $\mathrm{pH}$ immediately adjacent to the vent was still alkaline, despite being subjected to the equivalent of nearly 5,600 $\mathrm{ppm} \mathrm{CO}_{2}$. Other such sites are known around the world, such as the Champagne Reef, a premier diving site in Dominica, which is reported to be full of life. It is possible that the oceanic carbonate fixers are suffering $\mathrm{CO}_{2}$ starvation, just like terrestrial plants, which grow better under elevated $\mathrm{CO}_{2}$ levels. It is also possible that the vents emit other useful elements such as calcium.

As the modern investigation into the potential impacts of increasing carbon dioxide in seawater on marine life continues, one narrative is beginning to emerge across the scientific literature, which is that rising atmospheric $\mathrm{CO}_{2}$ concentrations will likely benefit the growth of primary 
producers. For example, Pardew et al. (2018) studied the growth responses of seven phytoplankton species from four major taxons to elevated levels of seawater $p \mathrm{CO}_{2}$. Each of the species was grown under controlled-environment conditions under either ambient $(\sim 500 \mu \mathrm{atm})$ or elevated $(\sim 1,000$ $\mu \mathrm{atm}) p \mathrm{CO} 2$ in either a high-nitrogen or low-nitrogen culture medium. They found the growth rates of all species increased with high $\mathrm{CO}^{2}$ independent of culture regime, where on average an increase of $0.12 \pm$ 0.07 per day was observed in phytoplankton exposed to high $\mathrm{CO}^{2}$ compared to ambient conditions $(p<0.001)$. The picture painted by this study is quite different from that sold to the public by climate alarmists, who consistently claim that so-called ocean acidification is detrimental to marine life.

In a comprehensive analysis of experimental studies that explored the effects of rising atmospheric $\mathrm{CO}_{2}$ concentrations on marine biota, Hendriks et al. (2010) assembled a database of 372 experimentally evaluated responses of 44 different marine species to ocean acidification that was induced by equilibrating seawater with $\mathrm{CO}_{2}$-enriched air. This they did because, as they describe it, warnings that ocean acidification is a major threat to marine biodiversity are largely based on the analysis of predicted changes in ocean chemical fields, which are derived from theoretical models that do not account for numerous biological phenomena and have only limited experimental support. They note that calcification is an active process where biota can regulate intracellular calcium concentrations, so that marine organisms, like calcifying coccolithophores (Brownlee and Taylor 2004), actively expel $\mathrm{Ca}^{2+}$ through the ATPase pump to maintain low intracellular calcium concentrations. They suggest, there is evidence that calcification could even increase in acidified seawater, contradicting the traditional belief that calcification is a critical process impacted by ocean acidification. In brief Hendriks et al. (2010) conclude that the world's marine biota are more resistant to ocean acidification than suggested by pessimistic predictions identifying ocean acidification as a major threat to marine biodiversity. Biological processes can provide homeostasis against changes in $\mathrm{pH}$ of surrounding water. All species, including marine calcifying species, are capable of controlling their internal chemistry in a wide range of external conditions.

A significant contribution was made by McCulloch et al. (2017) who studied Porites corals on reefs off Queensland and Western Australia from 2007 to 2012. They all exhibit strong seasonal changes in $\mathrm{pH}$ which represents an elevation of $\mathrm{pH}$ relevant to ambient seawater of $\sim 0.4 \mathrm{pH}$ units together with a relatively large seasonal range in $\mathrm{pH}$ of 0.2 units. They note that these observations are in stark contrast to the far more muted changes based on laboratory-controlled experiments which are an order of magnitude smaller than those actually observed in reef environments. The implications of these findings are enormous for they show that the $\mathrm{pH}$ upregulation occurs largely independent of changes in seawater carbonate chemistry, and hence ocean acidification (my underline) demonstrating the ability of the coral to 'control' what is arguably one of its most fundamental physiological processes, the growth of its skeleton within which it lives. This argument against ocean acidification is especially surprising coming from McCulloch et al. (2017) who is an ardent advocate of Anthropogenic Global Warming. I have seen him active in a demonstration at a talk by Anthony Watts, and he attempted to disrupt a lecture I myself gave at the University of Western Australia.

\section{Coral Bleaching}

There is a completely fake argument used by alarmists including NASA implying that coral bleaching is caused by carbon dioxide. Bleached coral is perfectly normal, and occurs when wave driven mixing ceases during periods of extended calm associated with unusual warming of the surface 1-2 $\mathrm{m}$ of seawater. The reef recovers in a few years by recolonization.

\section{Massive Carbonate Accumulations}

Minor amount of carbonate are found in many areas, such as small shelly beaches, but some areas with massive accumulation are much more important in global limestone production. Coral reefs are a major one, and data on this is presented below with the Great Barrier Reef as a prime example. Elsewhere there are exceptionally large accumulations of carbonate sands. Bourman et al. (2016) provide a good recent example of a study of such deposits from South Australia. The coasts are dominated by carbonate sands in the form of 
beaches and dunes. The authors frequently refer to the carbonate factory that produces carbonate sand, and even claim that the South Australian coast is part of the world's largest temperate carbonate factory. The sources of the sediment were a subtidal carbonate factory with the prolific growth of calcareous marine invertebrates such as molluscs, bryozoans, coralline algae, echinoids, and foraminifers. Attrition of their remains leads to the formation of sand-sized sedimentary particles of calcium carbonate.

In Gulf St Vincent seagrasses thrive with extremely productive calcareous algae, foraminifers and molluscs manufacturing vast amounts of calcareous sediment. The dominant processes of coastal development in Spencer Gulf are related to the massive production and accumulation of biogenic skeletal carbonate fragments derived from coralline algae, foraminifers, molluscs and bryozoans; the site is a major carbonate factory sequestering much $\mathrm{CO}_{2}$. The coastline of South Australia is part of the world's largest aeolianite (dune limestone) temperate sedimentary carbonate province, which extends from western Victoria to north of Shark Bay, Western Australia. The aeolianite deposits attest to the high calcium carbonate bioproductivity of the surrounding continental shelf environments (Bourman et al. 2016).

\section{The Great Barrier Reef}

The iconic Great Barrier Reef is one of the bestknown features of Australia, and we are constantly told it is in danger. The Australian Government's Great Barrier Reef Marine Park Authority (2019) claimed: In the long-term, ocean acidification is likely to be the most significant impact of a changing climate on the Great Barrier Reef ecosystem.

Another example is provided by Albright et al. (2016) who claim their research shows, the reduction in seawater $\mathrm{pH}$ - caused by carbon dioxide from human activities such as burning fossil fuels - is making it more difficult for corals to build and maintain their skeletons. Possibly the greatest danger to the Great Barrier Reef is the huge amount of money, tens of millions of dollars, made available for research on the reef. This has led to a feeding-frenzy of people wanting to use the money, who maintain that the reef is in danger, to keep the money flowing.
David Barnes has spent many hours measuring the $\mathrm{pH}$ in all parts of the reef. He tells me ...On the Great Barrier Reef water is pushed onto the front of reefs at around $p H$ 8.1-8.2. It then flows across the shallow reef flat and into the lagoon or back-reef area. The $\mathrm{pH}$ of water leaving the reef flat in the daytime is around 8.4-8.5. The $\mathrm{pH}$ of water leaving the reef flat at night is around 7.9-8.0. This shift is entirely due to removal of $\mathrm{CO}_{2}$ during the day because of photosynthesis by reef organisms, notably corals, coralline algae and ubiquitous, all-pervasive filamentous green algae (note that most of the significant calcifiers on reefs are photosynthetic; examples are green algae, foraminiferans and giant clams). During the day photosynthesis considerably exceeds respiration. During the night there is only respiration. Hence, at night, addition of $\mathrm{CO}_{2}$ to the water mass by respiration of benthic organisms decreases the $p H$. Notice that the organisms at the back of a reef flat are experiencing daily a shift in $\mathrm{pH}$ that our alarmist friends would have us believe will bring destruction to coral reefs if it had taken place in the water flowing onto a reef. Coral growth is usually at its most luxurious at the back of a reefflat (personal comm.).

The Great Barrier Reef has been able to re-establish itself repeatedly during high sea level episodes associated with major environmental fluctuations in sea level, temperature and $\mathrm{CO}_{2}$ over the past several hundred thousand years. The Great Barrier Reef complex goes back about two million years, but the reef, as we know it is only about 10,000 years old. Before that, there were huge changes in climate and sea level. Where the Great Barrier Reef complex is from tens to over a hundred $\mathrm{Km}$ in width today, it was reduced to a narrow fringing reef along the edge of a vast coastal plain during the last glacial period. It was not great and was not a barrier reef. It also experienced earlier glacial periods, with sea level falls. The Great Barrier Reef has survived many wide changes in environmental conditions, yet still ocean acidification is singled out by alarmists as the great threat to the reef.

\section{Geological History of Limestone and Carbon Dioxide}

Marine life depends on $\mathrm{CO}_{2}$, and some plants and animals fix it as limestone, which is not generally re-dissolved. Marine life, including that 
part that fixes $\mathrm{CO}_{2}$ as the carbonate in limestones such as coral reefs, evolved on an Earth with $\mathrm{CO}_{2}$ levels many times higher than those of today, as reported by Berner and Kothavala (2001). It may be true to say that today's marine life is surviving in a $\mathrm{CO}_{2}$-deprived environment. Over geological time enormous amount of $\mathrm{CO}_{2}$ have been sequestered by living things, so that today there is far more $\mathrm{CO}_{2}$ in limestones than in the atmosphere or ocean waters. This sequestration of $\mathrm{CO}_{2}$ by living things is far more important than trivial additions to the atmosphere caused by human activity. Carbon dioxide in seawater does not dissolve coral reefs or other marine limestones, but is essential to their survival.

In the grand geochemical cycle, carbon dioxide originates from volcanic eruptions and is fixed by limestone formation in the sea. Whether the Earth started as a hot or cold body, any primordial gas would have escaped. Volcanic eruptions produced the gases, including water, which formed the oceans, and carbon dioxide which formed $98 \%$ of the original atmosphere. The evolution of life changed that. When photosynthesis started, more and more oxygen was introduced into the atmosphere (which changed the course of rock weathering), and when carbonate secretion arrived in the late Precambrian, limestone deposition started to sequester $\mathrm{CO}_{2}$. The production of limestone became significant in the late Precambrian, and has increased through geological time.

Most modern reef coral genera have fossil histories going back from 5-10 million years to over 100 million years. They have survived both ice ages and very warm periods, and times when $\mathrm{CO}_{2}$ was at 5-10 times current levels.

Contrary to popular belief, at 400 parts per million $(0.04 \%), \mathrm{CO}_{2}$ is lower now in the atmosphere than it has been during most of the 550 million years since modern life forms emerged during the Cambrian period. $\mathrm{CO}_{2}$ was about 10 times higher than it is today. Corals and shellfish evolved early and have obviously managed to survive through eras of much higher $\mathrm{CO}_{2}$ than present levels. Finally, it is a fact that people who have saltwater aquariums sometimes add $\mathrm{CO}_{2}$ to the water in order to increase coral growth and to increase plant growth.

The truth is $\mathrm{CO}_{2}$ is the most important food for all life on Earth, including marine life. It is the main food for photosynthetic plankton (algae), which in turn is the start for the entire food chain in the sea. On top of this, some marine organisms use $\mathrm{CO}_{2}$ to produce their skeletons of calcium carbonate.

\section{Conclusion}

Marine life depends on $\mathrm{CO}_{2}$, and some plants and animals fix it as limestone, which is not generally re-dissolved. Over geological time enormous amount of $\mathrm{CO}_{2}$ have been sequestered by living things, so that today there is far more $\mathrm{CO}_{2}$ in limestones than in the atmosphere or ocean. This sequestration of $\mathrm{CO}_{2}$ by living things is far more important than trivial additions to the atmosphere caused by human activity.

The carbonate factories described here show that carbon dioxide is vital for the production of carbonate sands and ultimately limestone. Trying to reduce the carbon dioxide content of the ocean by reducing emissions by human activities is not only futile, but if it could be done it would have harmful consequences on all the carbonate fixing animals and plants in the ocean. The continued existence of the Great Barrier Reef, like coral reefs all over the world, depends on corals and other plants and animals fixing carbon dioxide as part of their skeletons, and as part of the carbon cycle. Carbon dioxide in seawater does not dissolve coral reefs, but is essential to their survival.

\section{References}

Albright R., Caldeira L, Hosfelt J., Kwiatkowski L., Maclaren J.K., Mason B.M., Nebuchina Y., Ninokawa A., Pongratz J., Ricke K.L., Rivlin T., Schneider K., Sesboüé M., Shamberger K., Silverman J., Wolfe K., Zhu K., Caldeira K., 2016. Reversal of ocean acidification enhances net coral reef calcification. Nature: 531: 362-365.

Australian Government's Great Barrier Reef Marine Park Authority. 2019. Online: www.gbrmpa.gov.au/ourwork/threats-to-the-reef/climate-change/ocean-acidification \%20 (accessed Juky 11, 2019)

Berner R.A., Kothavala Z., 2001. A revised model of atmospheric CO2 over Phanerozoic time. American Journal of Science 301: 182-204.

Bourman R.P., Murray-Wallace C.V., Harvey N., 2016. Coastal Landscapes of South Australia. University of Adelaide Press, Adelaide. 420pp. DOI: 10.20851/coast-sa.

Broecker W. 2011. Foreword. In: J.-P. Gasutto, L. Hansson (eds.), Ocean Acidification. Oxford University Press: v-vii.

Caldeira K., Wickett M.E., 2003. Anthropogenic carbon and ocean $\mathrm{pH}$. Nature 425: 365. 
Delingpole J. 2014. NOAAgate: how 'ocean acidification' could turn out to be the biggest con since Michael Mann's Hockey Stick. Brietbart, 23 December 2014.

Doogue J., Nova J., 2015. Oceans not acidifying - "scientist" hid 80 years of $\mathrm{pH}$ data. Online: joannenova.com. $\mathrm{au} / 2015 / 01$ / oceans-not-acidifying-scientists-hid-80years-of-ph-data/ (accessed July 11, 2019).

Feely R.A., Sabine C.L., Lee K., Berelson W., Kleypas J., Fabry VJ, Millero FJ., 2004. Impact of anthropogenic CO2 on the $\mathrm{CaCO} 3$ system in the oceans. Science 305(5682): 362-366.

Gasutto J.-P., Hansson L. (eds.), 2011. Ocean Acidification. Oxford University Press.

Hendriks I.E., Duarte C.M., Alvarez M., 2010. Vulnerability of marine biodiversity to ocean acidification: A meta-analysis. Estuarine, Coastal and Shelf Science 86: 157-164.

Henry W., 1803. Experiments on the quantity of gases absorbed by water, at different temperatures, and under different pressures. Philosophical Transactions of the Royal Society 93: 29-274. DOI: 10.1098/rstl.1803.0004.

Herfort L., Thake B., Taubner I., 2008. Bicarbonate stimulation of calcification and photosynthesis in two hermatypic corals. Journal of Phycology 44: 91-98.

IPCC [Intergovernmental Panel on Climate Change], 2018. Global Warming of $1.5^{\circ} \mathrm{C}$.An IPCC Special Report on the impacts of global warming of $1.5^{\circ} \mathrm{C}$ above pre-industrial levels and related global greenhouse gas emission pathways, in the context of strengthening the global response to the threat of climate change, sustainable development, and efforts to eradicate poverty [Masson-Delmotte, V., P. Zhai, H.-O. Pörtner, D. Roberts, J. Skea, P.R. Shukla, A. Pirani, W. Moufouma-Okia, C. Péan, R. Pidcock, S. Con- nors, J.B.R. Matthews, Y. Chen, X. Zhou, M.I. Gomis, E. Lonnoy, T. Maycock, M. Tignor, and T. Waterfield (eds.)]. Kerrison P., Hall-Spencer J., Suggett D., Hepburn L., Steinke M., .2011. Assessment of $\mathrm{pH}$ variability at a coastal $\mathrm{CO}_{2}$ vent for ocean acidification studies. Estuarine and Coastal Marine Science 94: 129-137.

Mcculloch M.T., D’olivo J.P., Falter J., Holcomb M., Trotter J.A., 2017. Coral calcification in a changing world and the interactive dynamics of $\mathrm{pH}$ and DIC upregulation. $\mathrm{Na}$ ture Communications 8: 15866.

NASA [National Aeronautics and Space Administration], 2019. Global Climate Change - Vital Signs of the Planet. Online: climate.nasa.gov/evidence/ (accessed July 11, 2019).

Pardew J., Pimentel M.B., Low-Decarie E., 2018. Predictable ecological response to rising $\mathrm{CO}_{2}$ of a community of marine phytoplankton. Ecology and Evolution 8: 4292-4302.

Segalstad T.V., 2014. Some thoughts on Ocean Chemistry. Nongovernmental International Panel on Climate Change (NIPCC), Reports Climate Change Reconsidered II - Biological impacts.: 817-823.

Starck W., 2010. Observations on Growth of Reef Corals and Sea Grass Around Shallow Water Geothermal Vents in Papua New Guinea. Quadrant Online 15 March 2010.

Wallace M., 2015. Ocean pH Accuracy Arguments Challenged with 80 Years of Instrumental Data. Watts Up With That, March 31, 2015. Online: wattsupwiththat. com/2015/03/31/ocean-ph-accuracy-arguments-challenged-with-80-years-of-instrumental-data/ (accessed July 11, 2019). 